\title{
EFFECT OF N-FORMS AND SOME BIO-STIMULANTS ON PRODUCTIVITY OF CUCUMBER: \\ 3- FRUIT QUALITY. \\ Hamail.A.F.*;M.S.Hamada**;E.A.Tartoura ${ }^{\star * *}$ and M.A. Abd El-Hady* \\ * Veget. \& Flori. Dept., Faculty of Agriculture, Damietta University. \\ ** Genetics Dept., Faculty of Agriculture, Damietta University. \\ ${ }^{\star * \star}$ Veget. \& Flori. Dept., Faculty of Agriculture Mansoura University.
}

\begin{abstract}
During the two successive summer seasons of 2011 and 2012, two field experiments were carried out in a private farm at El-Mahalla El-Kubra - Gharbia governorate to investigate the effect of nitrogen fertilization forms i.e. ammonium sulphate and calcium nitrate and some bio-stimulants i.e. humic acid, fulvic acid, EM and yeast extract under high temperature on fruit quality of cucumber (Cucumis sativus L.) Cv. Prince.

The results showed that the effect of $\mathrm{N}$-forms was significant on all cucumber fruits quality. The maximum values of these parameters were executed for the treatment of $\left(50 \% \mathrm{NH}_{4}+50 \% \mathrm{NO}_{3}\right)$.

Foliar spraying of cucumber plants with bio-stimulants significantly increased the mean values of fruits quality and decreased fruit contents of nitrate as compared with the control treatment. The best foliar application was (EM) effective microorganisms at $20 \mathrm{ml} / \mathrm{l}$.

Therefore, using nitrogen fertilization as $\left(50 \% \mathrm{NH}_{4}+50 \% \mathrm{NO}_{3}\right)$ combined with spraying (EM) at $20 \mathrm{ml} / \mathrm{l}$ could be recommended in case of high temperature conditions.

Keywords: Cucumber (Cucumis sativus) - fruit quality - $\mathrm{N}$-forms $\mathrm{NH}_{4}: \mathrm{NO}_{3}$ - biostimulants - humic acid - fulvic acid - effective Microorganisms (EM) yeast extract - high temperature.
\end{abstract}

\section{INTRODUCTION}

Cucumber crop (Cucumis sativus L.) is a major vegetable crop grown under all world regime. Although its calorie and nutritional value is very low, it is a primary source of vitamins and minerals in the human diet. In addition to its delicious taste and fairly good caloric value, it has high medicinal value for human beings. It is well known for natural diuretic and thus can serve as an active drug for secreting and promoting flow of urine. Due to high content of potassium (50-80 mg/100g), cucumber can highly be useful for both high and low blood pressures (Kashif et al., 2008). Compared with many crops, cucumber reaches harvest stage rapidly. The cucumber fruit products are used not only for fresh eating and culinary cooking, but also for salad and pickling.

The excess use of nitrogen fertilizers in agriculture can lead to nitrate accumulation in plants and ground water pollution. Nitrate accumulation in editable plants is a problem when eaten. Part of nitrate may be converted to nitrite causing methaemoglobinaemia or even to carcinogenic nitrosamines. Accordingly, active researches must be conducted to find ways of reducing nitrate accumulation in vegetables crops (Taha et al., 2011). 
At the present time, a great attention has been given to bio-stimulants as a management tool for increasing the quality of vegetable crops. Engaging in vegetable production the chemicals of regulatory effect on plant growth and development (biostimulators) are one of means for obtaining the increase in plant performance. However, plant biostimulation has recently become an increasingly more common treatment in modern agricultural production; among such substances are humic acid, fulvic acid, EM and yeast extract. Humic. Humic acid is the major acid extractable component of humic substances that can be applied directly to the plant foliage in liquid form or to the soil in the form of granules alone or as fertilizer mix. The importance of fulvic acid likes its ability to promote hormonal activity in plant (Clapp et al., 2002). Effective Micro-organism (EM) preparation are included population of lactic bacteria, yeast, smaller numbers of phototrophic bacteria, filamentous fungi and actinomycetes. For these reasons it can improve quality of crops. Active dry yeast is a natural bio-substance suggested to have stimulating, nutritional and protective functions when used on vegetables. Foliar application of yeast was found to increase growth, yield and quality of many vegetable crops (Arafa et al., 2012 and Shehata et al., 2012).

The aim of this study is to evaluate the growth characteristics and chemical constituents of cucumber in response to different $\mathrm{N}$-forms and some bio-stimulants treatments and their interactions under high temperature.

\section{MATERIALS AND METHODS}

Two field experiments were carried out at a private farm near El-Mahalla El-Kubra city, Gharbiya Governorate during the two successive summer seasons of 2011 and 2012, to investigate the effect of nitrogen forms and some bio-stimulants at high temperature on fruit quality of Cucumber (Cucumis sativus L.) cv. prince. Split plot design with three replicates in the both seasons was used in this study. Five treatments of $\mathrm{N}$-forms combinations $\left(\mathrm{NH}_{4}{ }^{+}: \mathrm{NO}_{3}{ }^{-}\right)$and five bio-stimulants (control, humic acid, fulvic acid, effective microorganisms (EM) and active dry yeast) were used in foliar way; Thus the experiment included 25 treatments as follows:

$$
\begin{aligned}
& \text { I. First factor ( } \mathrm{N} \text {-forms): } \\
& 1-\mathrm{N} 1=100 \% \mathrm{NH}_{4}^{+}+0 \% \mathrm{NO}_{3}^{-} . \quad 2-\mathrm{N} 2=75 \% \mathrm{NH}_{4}^{+}+25 \% \mathrm{NO}_{3}^{-} \text {. } \\
& \text { 3- } \mathrm{N3}=50 \% \mathrm{NH}_{4}^{+}+50 \% \mathrm{NO}_{3}^{-} . \quad 4-\mathrm{N} 4=25 \% \mathrm{NH}_{4}^{+}+75 \% \mathrm{NO}_{3}^{-} \text {. } \\
& \text { 5- } \mathrm{N} 5=0 \% \mathrm{NH}_{4}{ }^{+}+100 \% \mathrm{NO}_{3}{ }^{-} \text {. }
\end{aligned}
$$

II. Second factor (Bio-stimulants treatments):

1- Control (tap water).

2- Humic acid $20 \mathrm{~m} / \mathrm{l}$.

3- Fulvic acid $20 \mathrm{~m} / \mathrm{l}$.

4- EM $20 \mathrm{~m} / \mathrm{l}$.

5- Active dry yeast $10 \mathrm{~g} / \mathrm{l}$.

All bio-stimulants were used in the foliar way.

The seeds of cucumber (Cucumis sativus L. cv. prince) were sowing in the fourth week of june in both seasons of the study. Cucumber seeds were sown in hills handly at $30 \mathrm{~cm}$ distance between seeds on ridges. The plot area was $9 \mathrm{~m}^{2}(1.5 \mathrm{~m} \times 6 \mathrm{~m})$.

The physical and chemical properties of the experimental soil have presented in Table (1). 
Table (1): Physical and chemical analysis of the experimental soil during 2011 and 2012 seasons.

\begin{tabular}{|l|c|c|c|c|c|c|}
\hline Seasons & $\begin{array}{c}\text { O.M } \\
\%\end{array}$ & $\begin{array}{c}\mathrm{CaCO}_{3} \\
\%\end{array}$ & $\begin{array}{c}\text { Coarse } \\
\text { sand\% }\end{array}$ & $\begin{array}{c}\text { Fine Sand } \\
\%\end{array}$ & $\begin{array}{c}\text { Silt } \\
\%\end{array}$ & $\begin{array}{c}\text { Clay } \\
\%\end{array}$ \\
\hline 2011 & 2.45 & 1.97 & 1.92 & 18.33 & 32.21 & 47.54 \\
\hline 2012 & 2.19 & 2.09 & 2.37 & 18.46 & 33.26 & 45.91 \\
\hline
\end{tabular}

Table 1: continued

\begin{tabular}{|l|c|c|c|c|c|c|}
\hline $\begin{array}{l}\text { S.P } \\
\%\end{array}$ & \multicolumn{3}{|c|}{ Available (ppm) } & \multirow{2}{*}{ Texture class } & \multirow{2}{*}{$\mathbf{E C} C^{\star *} \mathbf{d s} / \mathbf{m}$} & \multirow{2}{*}{$\mathbf{p H}^{*}$} \\
\cline { 2 - 7 } & $\mathbf{P}$ & $\mathbf{K}$ & Clay & 1.03 & 7.83 \\
\hline 59 & 58.6 & 5.1 & 328 & Clay & 0.98 & 7.96 \\
\hline 57 & 53.9 & 4.7 & 315 & &
\end{tabular}

*Soil suspension (1:2.5) * Soil extraction (1:5)

Nitrogen fertilizer was added in the forms of Ammonium sulphate [ $(\mathrm{NH} 4) 2 \mathrm{SO} 4 ; 20.6 \% \mathrm{~N}$ ] as a source of $\mathrm{NH}_{4}{ }^{-}$and Calcium nitrate [ $\mathrm{Ca}(\mathrm{NO} 3) 2$, $15.5 \% \mathrm{~N}$ ] as a source of $\mathrm{NO}_{3}{ }^{-}$. These fertilizers were added at the level 100 $\mathrm{kg} \mathrm{N} / \mathrm{fed}$. The given doses were divided into two equal parts; the first at 21 days from planting and the other at two weeks later in both seasons.

Humic acid, fulvic acid and EM were obtained from Ministry of Agriculture, and foliarly applied at the rates of $20 \mathrm{ml} / \mathrm{l}$ for each. The control treatment was sprayed with tap water. Yeast extract: Backer's yeast mixed with sugar at ratio of 1:1 and left for 3 hours at room temperature. Then it was frozen for disruption of yeast tissue and releasing their content. Prepration of yeast extract was done according to El-Ghamriny et al. (1999) at the rates of $10 \mathrm{~g} / \mathrm{l}$. All the treatments of bio-stimulants were foliarly applied at two stages; one after two weeks from sowing and the other 7 days later.

Marketable fresh fruits were taken to determine:

- Chlorophyll content: was estimated as the method described by Goodwine (1965).

- Total nitrogen content: was determined in dried plant materials by using Keldahl methods described by Jackson (1967).

- Total phosphorus content: was determined using methods described by (Jackson 1967).

- Potassium content: was determined in the digested plant materials using a flame photometer according to Black (1965).

In addition, a hand refractometer was used for measuring total soluble solids (TSS) in fresh fruits.

- Ascorbic acid (Vitamin C): It was determined using the indophenols method (2, 6-dichlorophenolindophenol) as described by Ranganna (1979).

- Nitrate and Nitrite: Which was determined by using methods of Singh (1988).

The obtained data were subjected to statistical analysis as split plot design with three replicates in the both seasons according to Gomez and Gomez (1984).The differences between the treatments were compared using least significant differences (L.S.D) as described by Snedecor and Cochran (1967). 


\section{RESULTS AND DISCUSSION}

\section{Fruit quality:}

Concerning the effect of $\mathrm{N}$-forms on nitrogen, phosphorus, potassium and total chlorophyll contents in fruits, data presented in Table (2), The results show that all of these contents were significantly increased with the third form of $\mathrm{N}$ fertilization during the both seasons. It could be concluded that chlorophyll contents was increased by $\mathrm{Ca}\left(\mathrm{NO}_{3}\right)_{2}$ additions more than $\left(\mathrm{NH}_{4}\right)_{2} \mathrm{SO}_{4}$. This can be attributed to that $\mathrm{Ca}\left(\mathrm{NO}_{3}\right)_{2}$ gives the plant more chance to absorb more $\mathrm{N}$ and in turn to build more chlorophyll molecules. Nitrogen is considered as the backbone in the chlorophyll structure. Increasing of photosynthetic pigments may be due to increasing magnesium and iron, which are required for chlorophyll biosynthesis.

These results are in the same line with those reported by Tartoura (2001) and El-Deweny (2011). Generally, the positive response of the chemical constituents could be attributed to the source of $\mathrm{N}$-fertilizer for the plants treated with N3 treatment. It is residually acid forming. Whereas, the sources of $\mathrm{N}$ fertilizers for the plants treated with $\mathrm{N} 4$ treatment were ammonium sulfate and calcium nitrate. These $\mathrm{N}$-fertilizers are residually acid and basic forming. Continued use of these $\mathrm{N}$ fertilizers can affect $\mathrm{pH}$ of soil and make these elements in rooting zone soluble and availability form encouraged the plant to absorb more of them, consequently the uptake of the elements was increased (Hartmann et al., 1988).

Table (2): Effect of $\mathrm{N}$-forms and bio-stimulants applications at high temperature of cucumber on some chemical constituents in fruits of cucumber during 2011 and 2012 seasons.

\begin{tabular}{|c|c|c|c|c|c|c|c|c|}
\hline \multirow{2}{*}{\begin{tabular}{|l|} 
Characters \\
Treatments
\end{tabular}} & \multicolumn{2}{|c|}{$\mathbf{N} \%$} & \multicolumn{2}{|c|}{ P \% } & \multicolumn{2}{|c|}{ K\% } & \multicolumn{2}{|c|}{$\begin{array}{l}\text { Total chl. } \\
\text { (mg/g fw) }\end{array}$} \\
\hline & 2011 & 2012 & 2011 & 2012 & 2011 & 12 & 2011 & 2012 \\
\hline \multicolumn{9}{|c|}{ A: Nitrogen form } \\
\hline $\mathrm{H}_{4}^{+}+0 \% \mathrm{NO}_{3}$ & .98 & 0.96 & 0.073 & 0.086 & 0.472 & 551 & 0.807 & 0.771 \\
\hline $75 \% \mathrm{NH}_{4}^{+}+25 \% \mathrm{NO}_{3}$ & 1.35 & 1.39 & 0.114 & 0.125 & 0.752 & 0.789 & 0.894 & 0.850 \\
\hline $50 \% \mathrm{NH}_{4}{ }^{+}+50 \% \mathrm{NO}_{3}$ & 1.75 & 1.86 & 0.154 & 0.170 & 1.120 & 1.065 & 0.973 & 0.945 \\
\hline $25 \% \mathrm{NH}_{4}^{+}+75 \% \mathrm{NO}_{3}$ & 1.55 & 1.59 & 0.133 & 0.145 & 0.974 & 0.940 & 0.941 & 0.901 \\
\hline$+100 \% \mathrm{NO}_{3}$ & 1.17 & 1.15 & 0.093 & 0.107 & 0.609 & 43 & 0.863 & 0.832 \\
\hline LS & 0.02 & 0.03 & 0.002 & 0.002 & 0.049 & 0.024 & 0.003 & 0.005 \\
\hline \multicolumn{9}{|c|}{ B: Bio-stimulants } \\
\hline & 1.29 & 1.32 & 0.105 & 0.118 & 0.729 & 0.744 & 0.880 & 0.843 \\
\hline $\mathrm{Hu}$ & 1.32 & 1.36 & 0.110 & 0.123 & 0.763 & 0.779 & 0.889 & 0.854 \\
\hline Fulvic & 1.36 & 1.40 & 0.114 & 0.127 & 0.772 & 0.796 & 0.897 & 0.862 \\
\hline EM & 1.42 & 1.44 & 0.120 & 0.133 & 0.843 & 0.843 & 0.908 & 0.874 \\
\hline & .40 & 1.42 & 0.117 & 0.132 & 0.819 & 0.827 & 0.903 & 0.868 \\
\hline 10 & .03 & 0.03 & 0.002 & 0.002 & 0.039 & 0.025 & 0.003 & 0.003 \\
\hline
\end{tabular}


Data given in Table (3) show that N, P, K and total chlorophyll concentration were increased significantly under spraying plants with humic acid, fulvic acid, EM and yeast extract with $\mathrm{N}$-forms. The highest values came from treated plants with $50 \% \mathrm{NH}_{4}+50 \% \mathrm{NO}_{3}$ combined with spraying EM.

Table (3):Interaction effect between $\mathrm{N}$-forms and bio-stimulants applications at high temperature of cucumber on some chemical constituents in fruits of cucumber during 2011 and 2012 seasons.

\begin{tabular}{|c|c|c|c|c|c|c|c|c|c|}
\hline \multirow{2}{*}{\multicolumn{2}{|c|}{$\begin{array}{l}\text { Characters } \\
\text { Treatments }\end{array}$}} & \multicolumn{2}{|c|}{$\mathbf{N} \%$} & \multicolumn{2}{|l|}{$\mathrm{P} \%$} & \multicolumn{2}{|l|}{$\mathrm{K} \%$} & \multicolumn{2}{|c|}{$\begin{array}{l}\text { Total chl. } \\
(\mathrm{mg} / \mathrm{g} \text { fw) }\end{array}$} \\
\hline & & 2011 & 2012 & 2011 & 2012 & 2011 & 2012 & 2011 & 2012 \\
\hline \multirow{5}{*}{$\mathrm{N} 1$} & Control & 0.92 & 0.89 & 0.066 & 0.079 & 0.410 & 0.493 & 0.797 & 0.755 \\
\hline & Humic acid & 0.93 & 0.92 & 0.070 & 0.082 & 0.460 & 0.533 & 0.800 & 0.767 \\
\hline & Fulvic acid & 0.96 & 0.94 & 0.074 & 0.087 & 0.470 & 0.550 & 0.808 & 0.772 \\
\hline & EM & 1.04 & 1.03 & 0.080 & 0.092 & 0.510 & 0.593 & 0.816 & 0.783 \\
\hline & $\begin{array}{l}\text { Yeast } \\
\text { extract }\end{array}$ & 1.03 & 1.00 & 0.074 & 0.089 & 0.510 & 0.587 & 0.812 & 0.779 \\
\hline \multirow{5}{*}{ N2 } & Control & 1.28 & 1.34 & 0.107 & 0.116 & 0.700 & 0.723 & 0.878 & 0.831 \\
\hline & Humic acid & 1.31 & 1.35 & 0.111 & 0.122 & 0.733 & 0.787 & 0.890 & 0.843 \\
\hline & Fulvic acid & 1.35 & 1.38 & 0.114 & 0.128 & 0.667 & 0.777 & 0.895 & 0.853 \\
\hline & EM & 1.41 & 1.45 & 0.119 & 0.129 & 0.847 & 0.847 & 0.906 & 0.865 \\
\hline & $\begin{array}{c}\text { Yeast } \\
\text { extract }\end{array}$ & 1.38 & 1.42 & 0.117 & 0.131 & 0.813 & 0.813 & 0.901 & 0.859 \\
\hline \multirow{5}{*}{ N3 } & Control & 1.66 & 1.75 & 0.143 & 0.160 & 1.053 & 0.997 & 0.951 & 0.929 \\
\hline & Humic acid & 1.69 & 1.84 & 0.150 & 0.166 & 1.077 & 1.057 & 0.963 & 0.939 \\
\hline & Fulvic acid & 1.77 & 1.89 & 0.154 & 0.170 & 1.133 & 1.063 & 0.978 & 0.947 \\
\hline & EM & 1.85 & 1.92 & 0.162 & 0.179 & 1.183 & 1.127 & 0.989 & 0.956 \\
\hline & $\begin{array}{l}\text { Yeast } \\
\text { extract }\end{array}$ & 1.80 & 1.88 & 010 & 0.178 & 145 & 100 & 00 & 2 \\
\hline \multirow{5}{*}{ N4 } & Control & 1.48 & 1.52 & 0.126 & 0.136 & 0.930 & 0.900 & 0.925 & 0.885 \\
\hline & Humic acid & 1.53 & 1.55 & 0.127 & 0.143 & 0.950 & 0.913 & 0.937 & 0.894 \\
\hline & Fulvic acid & 1.55 & 1.62 & 0.135 & 0.144 & 0.970 & 0.947 & 0.941 & 0.902 \\
\hline & EM & 1.59 & 1.63 & 0.141 & 0.151 & 1.033 & 0.973 & 0.956 & 0.917 \\
\hline & $\begin{array}{l}\text { Yeast } \\
\text { extract }\end{array}$ & 1.59 & 1.63 & 0.136 & 0.150 & 0.987 & 0.967 & 0.945 & 0.907 \\
\hline \multirow{5}{*}{ N5 } & CSontrol & 1.11 & 1.09 & 0.085 & 0.098 & 0.553 & 0.606 & 0.849 & 0.815 \\
\hline & Humic acid & 1.14 & 1.13 & 0.090 & 0.104 & 0.597 & 0.607 & 0.855 & 0.825 \\
\hline & Fulvic acid & 1.16 & 1.18 & 0.093 & 0.108 & 0.620 & 0.643 & 0.863 & 0.835 \\
\hline & EM & 1.22 & 1.18 & 0.099 & 0.112 & 0.640 & 0.677 & 0.872 & 0.846 \\
\hline & $\begin{array}{l}\text { Yeast } \\
\text { extract }\end{array}$ & 1.19 & 1.16 & 0.098 & 0.110 & 0.633 & 0.683 & 0.874 & 0.841 \\
\hline \multicolumn{2}{|c|}{ LSD } & 0.06 & 0.06 & 0.005 & 0.004 & 0.089 & 0.054 & 0.007 & 0.008 \\
\hline
\end{tabular}

$\mathrm{N} 1=100 \% \mathrm{NH}_{4}^{+}+0 \% \mathrm{NO}_{3}^{-} \quad \mathrm{N} 2=75 \% \mathrm{NH}_{4}^{+}+25 \% \mathrm{NO}_{3}^{-} \quad \mathrm{N} 3=50 \% \mathrm{NH}_{4}^{+}+50 \% \mathrm{NO}_{3}^{-}$ $\mathrm{N} 4=25 \% \mathrm{NH}_{4}^{+}+75 \% \mathrm{NO}_{3}^{-} \quad \mathrm{N} 5=0 \% \mathrm{NH}_{4}^{+}+100 \% \mathrm{NO}_{3}^{-}$

Regarding the effect of bio-stimulants on nitrogen, phosphorus, potassium and total chlorophyll contents in fruits, Data in the same table show that different bio-stimulants caused significant increase in N, P and $\mathrm{K}$ contents. The highest values were obtained from planted sprayed with EM followed by yeast extract. 
Stimulative the uptake of macro- and microelements by humic acid that could be due to increase water consumption by plants accompanied with increase of nutrient uptake which is known to be involved in plant growth by enhance increasing the permeability of membranes of root cells due to improving root growth and development where application of humic acid stimulate root growth, increased proliferation of root hairs, production of smaller but more ramified secondary roots and enhancement of root initiation (Liu et al., 1998). This hypothesis was confirmed by significant increase in nitrogen, phosphorous and potassium in treated plant.

The effect of fulvic acid may be attributed to the known role of some elements like nitrogen which was found in such important molecules as prophyrin. The prophyrin structure was found in metabolically important compounds in chlorophyll (Develin, 1979). The increase in N, P and $\mathrm{K} \%$ in leaves as a result of spraying of fulvic acid may be due to the promotive effect of the plant growth substances, hence more nutrients might be absorbed to build up the plant organs and metabolites. These results are in harmony with those of Khalil et al. (2011) and Soliman (2011) on cucumber.

The enhancing effects of EM on chlorophylls concentration and their content may be due to their effects on increasing not only mineral uptake but also the production of growth substances especially cytokinins (Omay et al., 1993). Cytokinins are known to stimulate chlorophyll synthesis and delay chlorophyll destruction and senescence. The favorable effect of EM on P content may be due to its fundamental role in converting fixed $P$ form to be available for plant nutrition making the uptake of nutrients by plants more easy (Abou-Hussein et al., 2002). The increase in $\mathrm{K}$ content under $\mathrm{EM}$ reflects an enhanced growth which might be possible due to the role of microorganisms in increasing K-uptake (El-Shahawy, 2003).

Stimulative effect of yeast extract on photosynthetic pigments may due to a beneficial role during vegetative growth through enhancement the chlorophyll formation and photosynthetic efficiency due to its content of vitamins and amino acids which increased the metabolic processes role and levels of endogenous hormones, i.e. IAA and $\mathrm{GA}_{3}$ and endogenous cytokinins which have been established to induce the biosynthesis of chloroplast pigments, in turn retard senescence. The enhancable effect of yeast extract on N, P and K may be attributed to increases of leaf area and photosynthetic pigments thus increase photosynthesis process and hence more photosynthates being created as well as enhancement of mineral translocation from roots to leaves and fruits. This observation agrees with the report of Shehata et al. (2012) on cucumber and Wanas (2006) on squash

The effect of $\mathrm{N}$-forms on $\mathrm{No}_{2}-\mathrm{N}, \mathrm{No}_{3}-\mathrm{N}$ vit. $\mathrm{C}$ and T.S.S. contents in cucumber fruits, are presented in Table (4), The results show that there was a significant differences between $\mathrm{N}$-forms for nitrite and nitrate contents. The lowest one (1.37 and 49.92) in the first season and (1.33 and 49.27) in the second season were obtained from the plant fertilized with $\mathrm{N} 1\left(100 \% \mathrm{NH}_{4}{ }^{+}+\right.$ $0 \% \mathrm{NO}_{3}{ }^{-}$) for $\mathrm{No}_{2}-\mathrm{N}$ and $\mathrm{No}_{3}-\mathrm{N}$, respectively. While the highest values of $\mathrm{Vit}$. $\mathrm{C}$ and T.S.S. were obtained from the plants fertilized with $50 \% \mathrm{NH}_{4}{ }^{+}+50 \%$ $\mathrm{NO}_{3}{ }^{-}$ 
Data at the same table revealed that $\mathrm{No}_{2}-\mathrm{N}$ and $\mathrm{No}_{3}-\mathrm{N}$ were significantly decreased with spraying bio-stimulants. The lowest values were obtained from plants sprayed with EM. Also foliar spraying of EM as foliar amendments generally was associated with the highest contents of Vit. C and T.S.S.

Table (4): Effect of $\mathrm{N}$-forms and bio-stimulants applications at high temperature of cucumber on some fruit quality of cucumber during 2011 and 2012 seasons.

\begin{tabular}{|l|c|c|c|c|c|c|c|c|}
\hline Characters & $\mathbf{N o}_{2} \mathbf{N}(\mathbf{p p m})$ & $\mathbf{N o}_{\mathbf{3}} \mathbf{N}(\mathbf{p p m})$ & \multicolumn{1}{|c|}{ V.C (mg/100g) } & \multicolumn{2}{c|}{ T.S.S. \% } \\
\hline Treatments & $\mathbf{2 0 1 1}$ & $\mathbf{2 0 1 2}$ & $\mathbf{2 0 1 1}$ & $\mathbf{2 0 1 2}$ & $\mathbf{2 0 1 1}$ & $\mathbf{2 0 1 2}$ & $\mathbf{2 0 1 1}$ & $\mathbf{2 0 1 2}$ \\
\hline \multicolumn{8}{|c|}{ A: Nitrogen form } \\
\hline N1 & 1.37 & 1.33 & 49.92 & 49.27 & 3.30 & 3.58 & 4.99 & 5.14 \\
\hline N2 & 1.47 & 1.41 & 52.59 & 51.53 & 3.95 & 4.04 & 5.39 & 5.51 \\
\hline N3 & 1.55 & 1.48 & 55.32 & 54.07 & 4.71 & 4.54 & 5.98 & 5.84 \\
\hline N4 & 1.62 & 1.58 & 57.73 & 56.46 & 4.30 & 4.28 & 5.71 & 5.67 \\
\hline N5 & 1.76 & 1.66 & 61.13 & 59.45 & 3.63 & 3.80 & 5.23 & 5.32 \\
\hline LSD & $\mathbf{0 . 0 3}$ & $\mathbf{0 . 0 2}$ & $\mathbf{0 . 4 7}$ & $\mathbf{0 . 3 4}$ & $\mathbf{0 . 0 1}$ & $\mathbf{0 . 0 2}$ & $\mathbf{0 . 1 0}$ & $\mathbf{0 . 0 2}$ \\
\hline \multicolumn{8}{|c|}{ B: Bio-stimulants } \\
\hline Control & 1.62 & 1.55 & 56.03 & 54.96 & 3.86 & 3.97 & 5.32 & 5.41 \\
\hline Humic acid & 1.58 & 1.51 & 55.71 & 54.68 & 3.92 & 4.01 & 5.43 & 5.47 \\
\hline Fulvic acid & 1.56 & 1.50 & 55.47 & 54.15 & 3.99 & 4.05 & 5.48 & 5.50 \\
\hline EM & 1.48 & 1.43 & 54.57 & 53.25 & 4.08 & 4.12 & 5.54 & 5.57 \\
\hline Yeast extract & 1.52 & 1.48 & 54.92 & 53.73 & 4.05 & 4.09 & 5.52 & 5.53 \\
\hline LSD & 0.03 & 0.02 & 0.32 & 0.42 & 0.02 & 0.03 & 0.08 & 0.03 \\
\hline
\end{tabular}

Concerning the interaction between $\mathrm{N}$-forms and bio-stimulants on $\mathrm{No}_{2}-\mathrm{N}$ and $\mathrm{No}_{3}-\mathrm{N}$ contents, data in table (5) revealed that $\mathrm{N}$-forms combined with spraying bio-stimulants decrease $\mathrm{No}_{2}-\mathrm{N}$ and $\mathrm{No}_{3}-\mathrm{N}$. The lowest values were obtained from planted fertilized with $\mathrm{N} 1\left(100 \% \mathrm{NH}_{4}+0 \% \mathrm{NO}_{3}\right.$ ) combined with EM. Also the interaction effect between $\mathrm{N}$-forms and bio-stimulants treatments had a significant effect on Vit. C and T.S.S. in two seasons. The highest values were obtained from plants fertilized with $50 \% \mathrm{NH}_{4}+50 \% \mathrm{NO}_{3}$ and sprayed with EM.

This general feature indicated that plants which receive $\mathrm{NO}_{3}$ ions are more active in $\mathrm{N}$-absorption than those receive $\mathrm{NH}_{4}$ ions. It may also be due to both factors. The first is $\mathrm{NO}_{3}$ ion itself and the second is $\mathrm{Ca}\left(\mathrm{NO}_{3}\right)_{2}$ salt. Regarding to $\mathrm{Ca}\left(\mathrm{NO}_{3}\right)_{2}$ : this salts has a solubility degree of $102 \%$, but $\left(\mathrm{NH}_{4}\right)_{2} \mathrm{SO}_{4}$ has $71 \%$ only (Hassan, 1984). Also, $\mathrm{Ca}\left(\mathrm{NO}_{3}\right)_{2}$ has better effect on soil salinity, its salt index for $\mathrm{Ca}\left(\mathrm{NO}_{3}\right)_{2}$ is 52.5 , but it for $\left(\mathrm{NH}_{4}\right)_{2} \mathrm{SO}_{4}$ is 69.00. Moreover, $\mathrm{Ca}\left(\mathrm{NO}_{3}\right)_{2}$ has a better effect on nodulation system and $\mathrm{N}$ fixation, since it arise the soil pH, whereas $(\mathrm{NH} 4)_{2} \mathrm{SO}_{4}$ below it (Abdel-Aziz, 1997). Regarding to $\mathrm{NO}_{3}$ ion itself: this ion is distributing to cover all soil profile because its negative charge but $\mathrm{NH}_{4}$ ion present only exchangeable form (positive charge) or fixed between clay minerals layers.

Regarding to free nitrate, it is also noticed that free nitrate realized so little increase with increasing the added dose of $\mathrm{Ca}\left(\mathrm{NO}_{3}\right)_{2}$, but it does not exceed or reach the permissible limit for animal or human consumption (2000 ppm $\mathrm{NO}_{3}-\mathrm{N}$ ) based on the dry weight as cited by Tartoura and El-Saei (2001). 
The beneficial effects of EM on reducing nitrate concentration in cucumber fruits may be due to inducing the accumulation and utilization of nitrate in plant to produce proteins (Hanafy et al., 2002).

Table (5):Interaction effect between $\mathrm{N}$-forms and bio-stimulants applications at high temperature of cucumber on some fruit quality of cucumber during 2011 and 2012 seasons.

\begin{tabular}{|c|c|c|c|c|c|c|c|c|c|}
\hline \multirow{2}{*}{\multicolumn{2}{|c|}{\begin{tabular}{|l} 
Characters \\
Treatments
\end{tabular}}} & \multicolumn{2}{|c|}{$\begin{array}{l}\mathrm{No}_{2} \mathrm{~N} \\
(\mathrm{ppm})\end{array}$} & \multicolumn{2}{|c|}{$\begin{array}{l}\mathrm{No}_{3} \mathrm{~N} \\
\text { (ppm) }\end{array}$} & \multicolumn{2}{|c|}{$\begin{array}{c}\text { V.C } \\
\text { (mg/100g) }\end{array}$} & \multicolumn{2}{|c|}{ T.S.S. \% } \\
\hline & & 2011 & 2012 & 2011 & 2012 & 2011 & 2012 & 2011 & 2012 \\
\hline \multirow{5}{*}{ N1 } & Control & 1.44 & 1.40 & 50.70 & 50.00 & 3.20 & 3.51 & 4.91 & 5.10 \\
\hline & Humic acid & 42 & 1.35 & 50.23 & 49.73 & 3.24 & 3.52 & & \\
\hline & Fulvic acid & 38 & 1.32 & 49.97 & 49.63 & 3.32 & 3.60 & 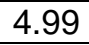 & 2 \\
\hline & EM & 1.27 & 1.28 & 49.27 & 48.27 & 3.37 & 3.64 & 5.05 & 5.20 \\
\hline & Yeast extract & 1.33 & 1.32 & 49.43 & 48.70 & 3.36 & 3.63 & 5.03 & 5.13 \\
\hline \multirow{5}{*}{ N2 } & Control & 1.53 & 1.48 & 53.10 & 52.23 & 3.82 & 3.96 & 5.06 & 5.42 \\
\hline & acid & 1.51 & 1.44 & 52.87 & 51.97 & 3.93 & 4.00 & 5.42 & 5.49 \\
\hline & $\mathrm{Fu}$ & 1.49 & 1.42 & 52.73 & 51.23 & 3.95 & 4.03 & 6 & 52 \\
\hline & EN & 1.37 & 1.33 & 51.90 & 50.87 & 4.04 & 4.11 & .50 & 53 \\
\hline & extrac & 1.42 & 1.39 & 52.37 & 51.33 & 4.03 & $4.0\}$ & .4 & 58 \\
\hline \multirow{5}{*}{ N3 } & Control & 1.62 & 1.52 & 55.80 & 54.80 & 4.59 & 4.41 & 0.86 & 5.63 \\
\hline & Humic acid & 1.57 & 1.50 & 55.67 & 54.67 & 4.64 & 4.49 & 5.90 & 5.78 \\
\hline & Fulvic acid & 1.55 & 1.49 & 55.53 & 53.93 & 4.72 & 4.53 & 5.98 & 5.87 \\
\hline & $\mathrm{EN}$ & 1.50 & 1.42 & 54.57 & 53.20 & 4.81 & 4.67 & 6.09 & 6.01 \\
\hline & & 1.53 & 1.46 & 55.03 & 53.77 & 4.79 & 4.59 & & 92 \\
\hline \multirow{5}{*}{ N4 } & & 1.68 & 1.62 & 58.17 & 56.93 & 4.15 & 4.22 & 5.62 & 5.60 \\
\hline & acid & 1.60 & 1.60 & 58.16 & 56.73 & 4.23 & 4.27 & 5.68 & 5.64 \\
\hline & Fulvic acid & 1.64 & 1.59 & 57.73 & 56.77 & 4.30 & 4.26 & 5.71 & 5.67 \\
\hline & EM & 1.56 & 1.52 & 57.23 & 55.67 & 4.45 & 4.33 & 5.77 & 5.74 \\
\hline & Yeas & 1.60 & 1.57 & 57.37 & 56.20 & 4.39 & 4.30 & 5.75 & 5.68 \\
\hline \multirow{5}{*}{ N5 } & & 1.82 & 1.72 & 62.40 & 60.83 & 3.52 & 3.74 & 5.14 & 5.29 \\
\hline & & 1.80 & 1.68 & 61.60 & 60.30 & 3.58 & 3.76 & 5.17 & 5.30 \\
\hline & Fulvic acid & 1.75 & 1.66 & 61.37 & 59.17 & 3.63 & 3.82 & 5.24 & 5.31 \\
\hline & EN & 1.71 & 1.60 & 59.90 & 58.27 & 3.73 & 3.86 & 5.31 & 5.39 \\
\hline & Yeast extract & 1.74 & 1.66 & 60.40 & 58.67 & 3.70 & 3.84 & 5.26 & 5.33 \\
\hline \multicolumn{2}{|c|}{ SD } & 0.07 & 0.04 & 0.76 & 0.88 & 0.04 & 0.05 & 0.19 & 0.05 \\
\hline
\end{tabular}

\section{REFERENCES}

Abdel-Aziz, M. A. (1997). Response of tomato plants to nitrogen fertilizer levels and growth regulators. M.Sc. Thesis, Dept. Vegetable Crops. Fac. Agric. Cairo Univ., Egypt.

Abdel-Latif, S.H. (1987). Study on utilization of some food industries waste in the production of single cell protein. M.Sc. Thesis, Fac. Agric. Moshtohor, Zagazig Univ. Egypt. 
Abou-Hussein, S.; I. El-Oksh; T. El-Shorbagy and A. Gomaa (2002). Effect of cattle manure, bio-fertilizers and reducing mineral fertilizer on nutrient content and yield of potato plant. Egypt J. Hort., 29(1): 99-115.

Arafa, A. A.; S. F. Hussien and H. S. Mohamed (2012). Response of tuber yield quality and quality of potato plants and its economic consideration to certain bioregulators or effective microorganisms under potassium fertilization. J. Agric. Sci. Mans. Univ., 3(1): 131-150.

Black, C. A. (1965). "Methods of soil analysis". Part 1. Physical and mineralogical. A.S.A. Madison, Wise., USA.

Clapp, C. E.; R. S. Vial; Y. Chen; A. J. Palazzo; V. W. Cline and J. M. Baker (2002). Stimulation of plant growth by humic substances ASA-CSSASSSA Annual Meeting Abstracts. Paper No. S03-clapp 125043-Poster.

Develin, R. M. (1979). Plant physiology. Third edtion Affiliated East-West. Press, New Delhi. P: 159-205.

El-Deweny, K. M. (2011). The effect of potassium and nitrogen form on long white radish yield. . M.Sc. Thesis, Fac. of Agric., Mans. Univ., Egypt.

El-Gamiely, E. E. (1988). Studies on onion crop (production factors). Ph.D. Thesis, Fac. of Agric., Mans. Univ.

El-Ghamriny, E. A.; H. M. Arisha and K. A. Nour (1999). Studies on tomato flowering, fruit set, yield and quality in summer season.1- Spraying with thiamine, ascorbic acid and yeast. Zagazig J. Agric. Res., 26(5): 13451364.

El-Shahawy, A. M. (2003). Effect of phosphate dissolving bacteria on yield and nutrient uptake of faba bean and wheat plants. Ph. D. Thesis, Fac. Of Agric. Mans. Univ., Egypt.

Gomez, K. A. and A. A. Gomez (1984). "Statistical Procedures for Agricultural Research". John Wiley and Sons, Inc., New York. pp: 680.

Goodwine, T. W. (1965). Quantitative analysis of the chloroplast pigments. Academic Press, London and New York.

Hanafy, A. H.; M. R. Nesiem; A. M. Hewedy and H. E. Salem (2002). Effect of organic manure, bio-fertilizers and NPK mineral fertilizers on growth, yield, chemical composition and nitrate accumulation of sweet pepper plants. Proceeding of the 2th Congress Recent Technologies in. Fac. of Agric., Cairo Univ., Egypt 28-30 October, pp. 932-955.

Hartmann, H. T.; V. E. Rubatzky and A. M. Kofranek (1988). Plant Science: Growth, Development and Utilization of Cultivated Plants. Published March 22nd 1988 by Prentice Hall ,Hardcover, 752 pages.

Hassan, A. A. (1984). Principles of vegetables production and technology of usual and green houses production. Al-Arabia Publishing House, Egypt (In Arabic) pp. 179.

Jackson, M. L. (1967). "Soil chemical Analysis". Printico-Hall of India, New Delhi.

Kashif, W.; Q. Kamran and M. Jilani (2008). Effect of Different Nitrogen Levels on Growth and Yield of Cucumber (Cucumis sativus L.). J. Agric. Res., 46(3): 259-266. 
Khalil, H. M.; L. M. Ali and A. A. Mahmoud (2011). Impact of applied humic and fulvic acids on the soil physic-chemical properties and cucumber productivity under protected cultivation conditions. J. Agric. Sci. Mans. Univ., 2(2): 183-201.

Liu, C.; J. Cooper and D. Bowman (1998). Humic acid application affects photosynthesis, root development and nutrient content of creeping bentgrass, Hort. Sci., 33: 1023-1025.

Omay, S.; W. Schmidt and P. Martin (1993). Indole acetic acid productivity by rhyzosphere bacterium Azospirillum brasilense C.D. under in vitro condition. Can. J. Microbiol., 39: 187-192.

Ranganna, S. (1979). Manual analysis of fruit and vegetable products Tata Mc Growth Hill Publishing Company limited, New Delhi, 634 P.

Raven, J.A. and F.A. Smith. (1976). Nitrogen assimilation and transport in vascular land plants in relation to intercellular $\mathrm{Ph}$ regulation. New Phytol., 76: 415-431.

Shehata, S. A.; Z. F. Fawzy and H. R. El-Ramady (2012). Response of cucumber plants to foliar application of chitosan and yeast under greenhouse conditions. Australian J. of Basic and Applied Sci., 6(4): 63-71.

Singh, I. P. (1988). A rapid method for determination of nitrate in soil and plant extracts. Plant and soil, 110: $137-139$.

Snedecor, W. G. and G. W. Cochran (1967). "Statistical Methods". Lowa State Univ. Press, Ame, USA. 6th Ed., PP.393.

Soliman, M. A. (2011). Optimizing of using the sea weeds and organic acids on cucumber production under drip irrigation system. Ph. D. Thesis, Fac. of Agric. Mans. Univ. Egypt.

Taha, A. A.; A. A. Mosa and S. A. Ahmed (2011). Role of micronutrients and antioxidants application in stimulating growth and yield of fresh edible vegetables. J. Agric. Sci. Mans. Univ., 2(2): 251-263.

Tartoura, E. A. (2001). Response of pea plants to yeast extract and two sources of $\mathrm{N}$-fertilizers. J. Agric. Sci. Mans. Univ., 26(12): 7887-7901.

Tartoura, E. A. and M. A. El-Saei (2001). Field evaluation of brown algae and two sources of $\mathrm{N}$-fertilization on pea plants. J. Agric. Sci. Mans. Univ., 26(7): 4593-4605.

Wanas, A. L. (2006). Response of some squash plants grown in winter season to some natural extracts and antioxidants. Annals of Agric. Sci. Moshtohor, 44(4): 1571-1591. 


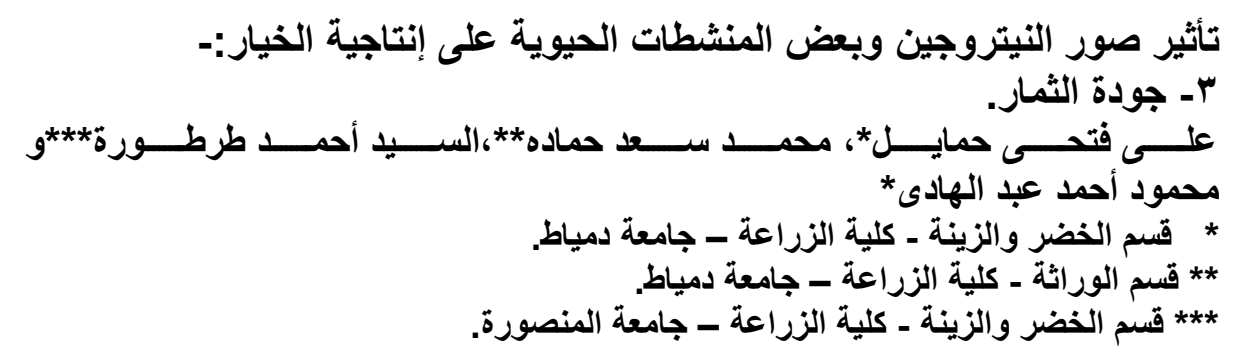

أجريت تجربتان حقليتان فى مزر عة خاصة بالقرب من المحلة الكبرى خلال موسمى الزراعة

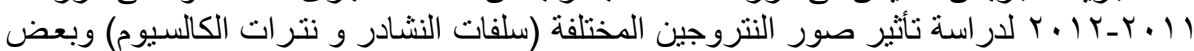

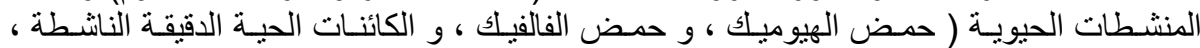

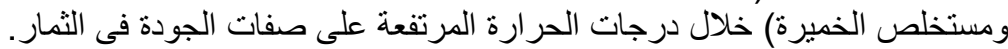

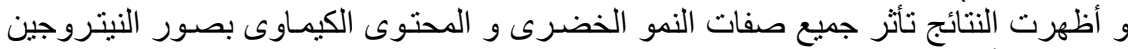

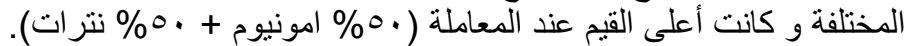

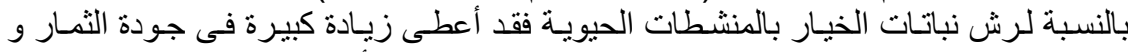

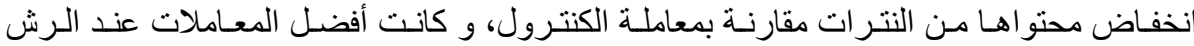

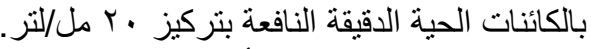

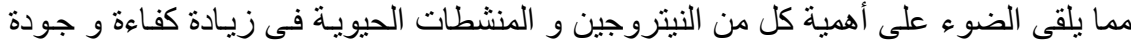

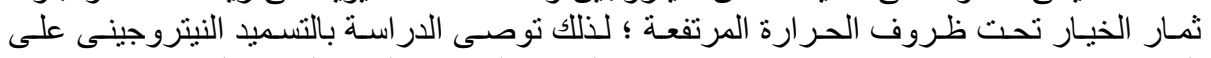

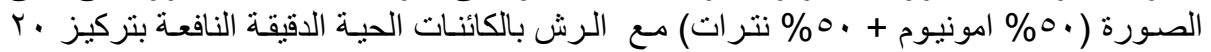
مل/ ملتر.

كلية الزراعة - جامعة المنصورة

قام بتحكيم البحث كلية الزراعة - جامعة عين شمس جاعس الزعة 